\title{
The application of modified layered double hydroxides in selective catalytic reduction of nitrogen oxides by ammonia $\left(\mathrm{NH}_{3}-\mathrm{SCR}\right)$
}

\author{
Agnieszka Szymaszek*, Monika Motak, Bogdan Samojeden \\ AGH University of Science and Technology, A. Mickiewicza 30, 30-059 Kraków, Poland \\ "Corresponding authors: e-mail: agnszym@agh.edu.pl
}

\begin{abstract}
Selective catalytic reduction with ammonia $\left(\mathrm{NH}_{3}\right.$-SCR) is very efficient DeNOx technique. According to some problems with the commercial catalyst, novel one should be prepared. Hydrotalcites are potential precursors of the new catalysts of $\mathrm{NH}_{3}$-SCR. In this paper, several attempts to apply these materials in $\mathrm{NH}_{3}$-SCR are presented.
\end{abstract}

Keywords: Yerba, antioxidant activity, infusions, minerals

\section{INTRODUCTION}

Among recent years a serious problem of excessive emission of nitrogen oxides $\left(\mathrm{NO}_{\mathrm{x}}\right)$ is observed. The presence of $\mathrm{NO}_{x}$ in the atmosphere has many dangerous consequences, including the formation of acid rains and photochemical smog or depletion of ozone layer. Moreover, nitrogen oxides are hazardous for humans health and aggravate the quality of the environment. Therefore, the implementation of official regulations according to $\mathrm{NO}_{\mathrm{x}}$ emission was required. One of the most important examples is EU directive 2010/75/EU that restrictively limits the permitted amount of $\mathrm{NO}_{\mathrm{x}}$ present in flue gases emitted from stationary and mobile sources ${ }^{1,2}$. The most efficient technology of $\mathrm{NO}_{\mathrm{x}}$ abatement is the selective catalytic reduction (SCR), mainly by ammonia. However, other reducers like hydrocarbons can be also used. Currently, the majority of industrial $\mathrm{DeNO}_{\mathrm{x}}$ systems exploit this method ${ }^{2-5}$. Generally, the technology is based on the reaction of nitrogen oxides with the reducing agent that is injected into the stream of flue gas. The desired products are molecular nitrogen and water vapour. The interaction between the reactants takes place on the surface of the catalyst that plays the essential role in the whole process. Additionally, depending on the nature and properties of the catalyst, the reaction can occur according to the mechanism of Langmuir-Hinshelwood (L-H) or Eley-Rideal (E-A). The first is based on simultaneous adsorption of $\mathrm{NH}_{3}$ and $\mathrm{NO}_{\mathrm{x}}$ on the catalyst surface and their consequent interaction. The second assumes that only ammonia is adsorbed on the catalyst surface and $\mathrm{NO}_{\mathrm{x}}$ are reduced during their flow through the catalyst saturated with $\mathrm{NH}_{3}{ }^{7}$. In Fig. 1. the simplified scheme of the $\mathrm{NH}_{3}$-SCR reaction is presented.

At the typical conditions $\left(300-400^{\circ} \mathrm{C}\right)$ the process is followed by the reaction $(1)^{6}$

$4 \mathrm{NH}_{3}+4 \mathrm{NO}+\mathrm{O}_{2} \rightarrow 4 \mathrm{~N}_{2}+6 \mathrm{H}_{2} \mathrm{O}$

In comparison to the other DeNO $\mathrm{N}_{\mathrm{x}}$ techniques, $\mathrm{NH}_{3}$ -SCR is the most effective, mainly due to the application of the catalyst that increases the selectivity of the reaction and therefore, reduces the amount of by-products. The most frequently used catalyst is alumina- or titania-supported $\mathrm{V}_{2} \mathrm{O}_{5}-\mathrm{WO}_{3}$ or $\mathrm{V}_{2} \mathrm{O}_{5}-\mathrm{MoO}_{3}$ in a monolithic form? However, the commercial catalyst has several drawbacks that limit its application and meeting the $\mathrm{NO}_{\mathrm{x}}$ emission standards. One of the most important obstacles is the narrow temperature window of the catalyst. The solution

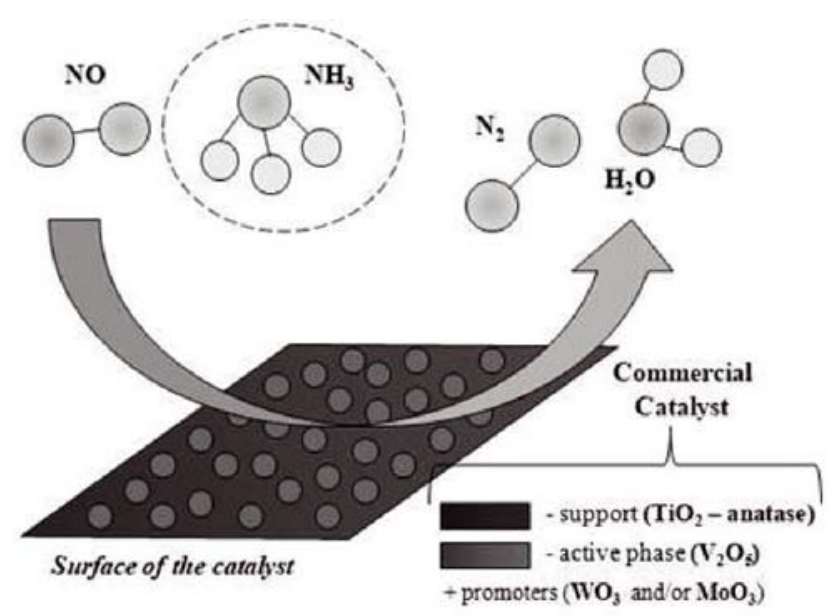

Figure 1. The scheme of $\mathrm{NH}_{3}-\mathrm{SCR}$ (based on: ${ }^{\mathbf{8}}$ )

might be placing the catalyst at the tail end, but in that case additional heating of the flue gas is required. On the other hand, placing the SCR installation upstream of electrostatic precipitator results in deactivation by the alkali metals and other contaminations present in the flue gas $3{ }^{30,11}$. According to these problems, there is an increasing interest in the development of a novel, efficient catalyst.

Layered double hydroxides (LDHs), known also as hydrotalcite-like compounds (HTlc) have been intensively investigated as potential catalysts and of many processes, including selective catalytic reduction of $\mathrm{NO}_{\mathrm{x}}{ }^{12-15}$. The layer structure of the natural hydrotalcite is closed to brucite, $\mathrm{Mg}(\mathrm{OH})_{2}$ in which a part of $\mathrm{Mg}^{2+}$ cations are replaced by $\mathrm{Al}^{3+}$. Electro-neutrality of the structure is provided by interlayer carbonate anions ${ }^{\mathbf{1 6}}$. What is more, hydrotalcite-like compounds possess anion-exchange properties and there is a wide range of organic and inorganic anions that can be introduced into the interlayer space. For instance, intercalation of polyoxometallates anionic metal complexes permits incorporation of at least one catalytically active component ${ }^{17,}{ }^{18}$. Due to direct synthesis of LDHs, and their unique features, e.g. ion-exchange properties and easy modulation of chemical composition, the materials can be successively applied in heterogeneous catalysis. Upon thermal decomposition, LDHs are transformed into mixed metal oxides. The active sites exhibit very high dispersion on the whole surface of the obtained material. Therefore the selectivity of a catalytic reaction can be significantly increased ${ }^{\mathbf{1 8}}$. According to the above, in this paper the 
structural features of LDHs, examples of incorporated interlayer anions and possibilities of their application as $\mathrm{NH}_{3}$-SCR catalysts are discussed.

\section{STRUCTURE OF LAYERED DOUBLE HYDROXIDES (LDHS)}

Layered double hydroxides are the group of materials that refer to "non-silicate oxides and hydroxides" with similar physiochemical properties to cationic clay minerals. Due to the variety of chemical composition, layer structure and ion-exchange properties of LDHs, the materials are often called as "clay mineral-like materials". However, in contrast to the layer silicate-based cationic clays, LDHs possess anion-exchange properties. Hence they are defined as anionic clays 16, 17, 19 .

The representative of LDHs is natural hydrotalcite. The material exhibits rhombohedral crystalline system with a three-layer repeat $(3 \mathrm{R})^{15}$. Its chemical formula, $\mathrm{Mg}_{6} \mathrm{Al}_{2}(\mathrm{OH})_{16} \mathrm{CO}_{3} \cdot 4 \mathrm{H}_{2} \mathrm{O}$ is the base for synthetic LDHs which have the following general notation $(2)^{20}$ :

$\left[\mathrm{M}_{1-\mathrm{x}}^{\mathrm{II}} \mathrm{M}^{\mathrm{III}}(\mathrm{OH})_{2}\right]^{\mathrm{x}+} \mathrm{A}_{\mathrm{x} / \mathrm{z}}^{\mathrm{z}-} \cdot \mathrm{nH}_{2} \mathrm{O}$

where $\mathrm{M}^{\mathrm{II}}$ and $\mathrm{M}^{\mathrm{III}}$ are di- and tri-valent cations, $\mathrm{A}$ - interlayered anions and $\mathrm{x}-$ molar ratio of cations $\mathrm{M}^{\mathrm{II}}$ and $\mathrm{M}^{\mathrm{III}}$ (commonly $\mathrm{x}$ oscillates around 0.15 and 0.34$)^{20}$.

As it was already mentioned, the structure of LDHs derives from brucite $-\mathrm{Mg}(\mathrm{OH})_{2}$, which comprises a close packing of $\mathrm{OH}^{-}$ions with octahedral sites every two layers occupied by $\mathrm{Mg}^{2+}$. In LDHs a fraction of $\mathrm{Mg}^{2+}$ ions is substituted by an ion $\mathrm{Al}^{3+}$. The exchange generates the excessive positive charge of the layers. Its compensation is provided by the introduction of interlayer anions $\mathrm{A}^{-}$. Apart from the anions, the interlayer space is occupied by water molecules. In Fig. 2. the idealized structure of LDHs is presented ${ }^{17,21}$.

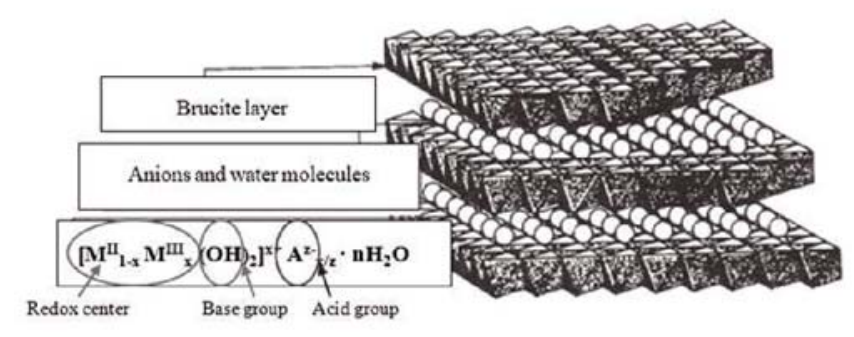

Figure 2. The structure of layered double hydroxide (based on: ${ }^{17}$ )

Hydrotalcite-like materials are very attractive for catalytic applications, especially due to the fact that interlayer anions can be easily exchanged in the way to obtain materials with desired catalytic. Therefore, intercalation of the wide variety of anions into LDHs is of great interest in many catalytic applications. Another thing is that above $400^{\circ} \mathrm{C}$ LDHs are thermally decomposed into mixed metal oxides or spinels with a considerable specific surface area and homogeneous distribution of introduced chemical components properties ${ }^{22,23}$.

\section{SYNTHESIS OF LAYERED DOUBLE HYDROXIDES (LDHS)}

Synthesis of the LDHs on both laboratory and industrial scale is easy and inexpensive. However, to obtain a pure LDHs phase, some specific precautions must be taken. The most significant concerns $\mathrm{pH}$ control and avoidance of the contact with atmospheric $\mathrm{CO}_{2}$ that can cause precipitation of impurities and contamination with $\mathrm{CO}_{3}{ }^{2-}$ ions $^{21}$. The most common route to prepare LDHs is co-precipitation at variable or constant $\mathrm{pH}$. Pure and chemically homogeneous materials are obtained upon synthesis at constant $\mathrm{pH}$. The influence of co-precipitation $\mathrm{pH}$ on the chemical, textural and structural properties of LDHs was confirmed in several works ${ }^{24-28}$. Practically, co-precipitation is based on adding a base solution to a solution containing a mixture of salts $\mathrm{M}^{\mathrm{II}}$ and $\mathrm{M}^{\mathrm{II}}$. While the $\mathrm{pH}$ is kept constant, $\mathrm{NaOH}, \mathrm{KOH}$ or $\mathrm{NH}_{3}$ are simultaneously added ${ }^{24}$. Although this LDHs preparation route is relatively simple and the obtained materials are repetitive, sometimes it is limited by competitive precipitation of metal salts (e.g. oxometalates) ${ }^{17}$.

Another method for the synthesis of LDHs is sol-gel route that involves the hydrolysis of metal alkoxides. The method is more expensive than co-precipitation, however it allows to obtain materials with enhanced specific surface area and higher thermal stability ${ }^{28,29}$. What is more, heating to the certain temperature (usually between $350-450^{\circ} \mathrm{C}$ ) results in the formation of mixed metal oxi$\mathrm{des}^{30,31}$. Interestingly, mixed metal oxides obtained upon thermal decomposition have a unique ability to retain the layer structure while they are exposed to aqueous solution. This specific property is commonly called as "memory effect" ${ }^{32}$.

There are also post-synthesis treatments that can be applied to "as-prepared" samples. These modifications are applied mainly due to the control of textural and structural parameters. For instance, microwaves used during the synthesis increase the porosity and specific surface area of the materials, while ultrasound radiation or hydrothermal reactions at high temperature improve their crystallinity ${ }^{33-35}$

\section{CATION-EXCHANGE PROPERTIES OF LDHS}

There is a wide range of cations that can be introduced into the brucite-like layers od LDHs. The only requirement of the exchange is that the radii of octahedral coordination is close to $\mathrm{Mg}^{\mathrm{II}}$ or $\mathrm{Al}^{\mathrm{III}}$. Therefore, $\mathrm{Mg}^{2+}$ and $\mathrm{Al}^{3+}$ can be replaced by divalent (e.g. $\mathrm{Cu}^{2+}$, $\mathrm{Ni}^{2+}, \mathrm{Co}^{2+}, \mathrm{Zn}^{2+}$ ) and trivalent (e.g. $\mathrm{Ga}^{3+}, \mathrm{Fe}^{3+}, \mathrm{Cr}^{3+}$, $\mathrm{V}^{3+}, \mathrm{Ru}^{3+}, \mathrm{Rh}^{3+}$ ) cations, respectively ${ }^{20}, 22$. Another crucial factor is to maintain the appropriate molar ratio of divalent and trivalent metals, in order to avoid the deformation of the octahedral structure. Additionally, some tetravalent cations such as $\mathrm{Ti}^{4+}, \mathrm{Zr}^{4+}$ or $\mathrm{Sn}^{4+}$ can be incorporated into brucite-like layer and form multi-metal cations with di- and trivalent metals. Table 1. shows the most common cations that replace $\mathrm{Mg}^{2+}$ and $\mathrm{Al}^{3+}$ in the brucite structure ${ }^{16,20}$. 
Table 1. Ionic radii of some of ion-exchanged cations in LDHs (based on: ${ }^{16,20}$ )

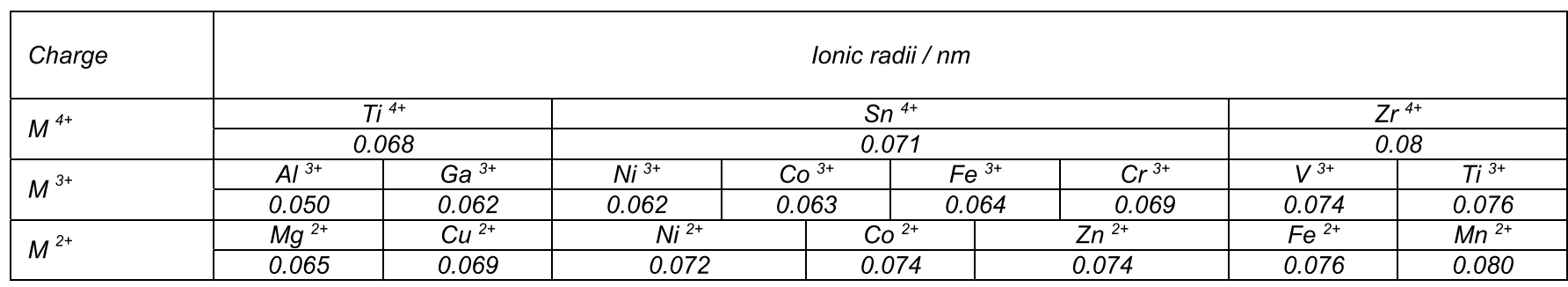

\section{ANION-EXCHANGE PROPERTIES OF LDHS}

The interlayer spaces of the LDHs can be intercalated with the wide range of inorganic or organic ions ${ }^{36}$. The examples of anions which can be introduced into LDHs structure are presented in Table 2. The anionic species present in the interlayer region can be mediated by columbic forces between the positively charged layers and negatively charged anions or by hydrogen bonding between hydroxyl groups of the anions and water molecules ${ }^{37}$. The anion-exchange capacity (AEC) is dependent on the $x$ (Eq. 2), while intercalation of the particular anion is related to the affinity of the anions in aqueous solution. For the interlayer region, this affinity is associated with the anions charge density and their size. More stable hydrotalcites are obtained while anionic charge increases, which is the result of stronger interaction between the positively charged hydroxide layer and the particulate anion ${ }^{17,37}$. Anion exchange is used in order to extend the chemical composition of LDHs. In some cases these materials can contain at least three different catalytically active metals which can spectacularly enhance their catalytic properties.

Table 2. The list of anions that can be introduced into LDHs interlayer space

\begin{tabular}{|c|c|}
\hline Inorganic anions & Organic anions \\
\hline $\begin{array}{l}\text { common inorganic ions (e.g. } \mathrm{Cl}^{-}, \\
\left.\mathrm{CO}_{3}{ }^{2-}, \mathrm{NO}_{3}^{-}\right)^{20} \\
\text { heteropoly acids (HPA) }{ }^{38} \\
\text { polyoxometallates (POMs) }{ }^{38,39} \\
\text { polyanions of transition metals }{ }^{41,42} \\
\text { complex anions }\end{array}$ & $\begin{array}{c}\text { carboxylates, dicarboxylates, } \\
\text { alkylsulfates }{ }^{19} \\
\text { metaloorganic complex }^{18} \\
\text { dyes }^{40} \\
\text { metalloporphyrins }^{41}\end{array}$ \\
\hline
\end{tabular}

\section{LDHs intercalated with metal-containing anions}

LDHs incorporated with metal-containing anions are especially interesting for catalytic applications. Some metals, such as molybdenum or vanadium cannot replace $\mathrm{Mg}^{2+}$ in the brucite layer, adequately due to their large ionic radius. These metals are very active components of the commercial SCR catalyst, thus their introduction into the structure of LDHs could potentially make the materials suitable for the process. It turns out that the metals can be successfully introduced into the LDHs interlayers as anionic species. There are some examples of materials which were already described in the literature, especially for vanadate and molybdate ions ${ }^{37,44,45}$.

\section{Vanadate anions}

The widest group of metal-containing anions that can be incorporated into the interlayer space of LDHs are oxovanadates. It was reported, that the polymerization degree of vanadium-containing anions strongly depends on $\mathrm{pH}$ maintained during the intercalation procedure.
When $\mathrm{pH}$ decreases, the nuclearity is increased ${ }^{46}$. Polymerization degree of oxovanadates in dependence on $\mathrm{pH}$ for a $0.1 \mathrm{M}$ aqueous vanadate solution is as it follows ${ }^{18,46}$ :

$$
\begin{aligned}
& \text { Decavanadate } \quad \mathbf{p H}=\mathbf{1 - 3} \\
& \mathrm{V}_{10} \mathrm{O}_{26}(\mathrm{OH})_{2}{ }^{4-}, \mathrm{V}_{10} \mathrm{O}_{27}(\mathrm{OH})^{5-}, \mathrm{V}_{10} \mathrm{O}_{26}{ }^{6-} \\
& \text { Metavanadate } \quad \mathbf{p H}=\mathbf{4 - 6} \\
& \mathrm{V}_{3}(\mathrm{OH})_{3}, \mathrm{VO}_{2}(\mathrm{OH}), \mathrm{V}_{3} \mathrm{O}_{9}^{3-}, \mathrm{V}_{4} \mathrm{O}_{12}{ }^{4-} \\
& \text { Pyrovanadate } \quad \mathbf{p H}=\mathbf{8 - 1 1} \\
& \mathrm{VO}_{3}(\mathrm{OH})^{2-}, \mathrm{HV}_{2} \mathrm{O}_{7}^{3-}, \mathrm{V}_{2} \mathrm{O}_{7}^{4-} \\
& \text { Vanadate } \quad \mathbf{p H}>\mathbf{1 2} \\
& \mathrm{VO}_{4}{ }^{2-}
\end{aligned}
$$

What is interesting, in case of pyrovanadate anions $\left(\mathrm{V}_{2} \mathrm{O}_{7}{ }^{4-}\right.$ and $\left.\mathrm{HV}_{2} \mathrm{O}_{7}^{3-}\right)$ which consist of two $\left[\mathrm{VO}_{4}\right]$ tetrahedra that share a vertex, two different arrangements in the interlayer space are possible. On one hand, V-V edge can be placed in a perpendicular position to the brucite-like layers and the basal spacing calculated from the size of $\mathrm{V}_{2} \mathrm{O}_{7}^{4-}$ is $12.6 \AA$. On the other hand, the anions can take the parallel position with the calculated basal spacing of $9.8 \AA$. The scheme of the pyrovanadate anions positions in the interlayer space are presented in Fig. 3. ${ }^{18,47}$.

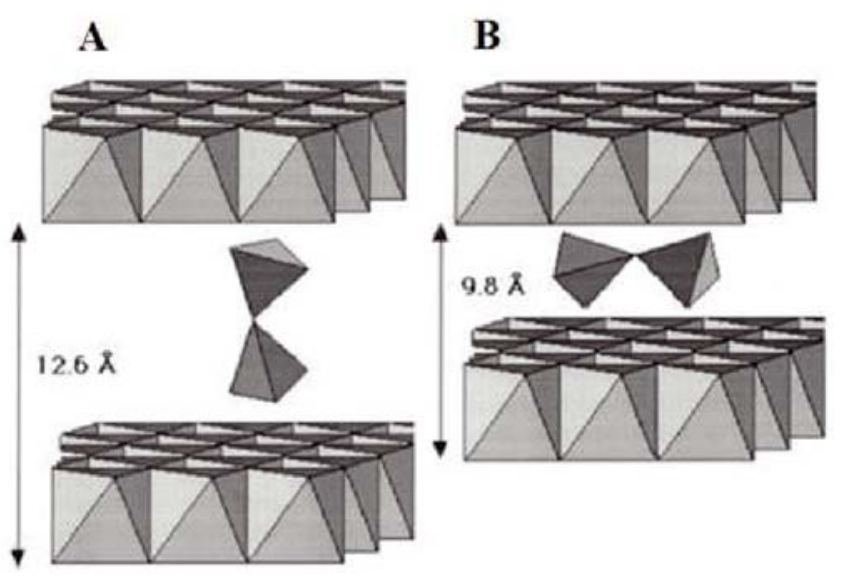

Figure 3. Possible orientations of $\mathrm{V}_{2} \mathrm{O}_{7}{ }^{2-}$ in LDHs - perpendicular (A) and parallel (B) (based on: ${ }^{18,47}$ )

Palmer et al. ${ }^{37}$ took the interesting attempt to describe the manner of inclusion of the anions into interlayer LDHs space. The authors indicated that these species can be intercalated or adsorbed into/onto hydrotalcite structures, in dependence on the $\mathrm{Mg} / \mathrm{Al}$ ratio. The materials described in the research were obtained by the co-precipitation method. The mixed metal solution of $\mathrm{Mg}^{2+}$ and $\mathrm{Al}^{3+}$ of the appropriate $\mathrm{Mg} / \mathrm{Al}$ ratio that results in formation of hydrotalcite structure was added dropwise to the mixture of $\mathrm{NaOH}, \mathrm{Na}_{2} \mathrm{CO}_{3}$ and 
$\mathrm{Na}_{2} \mathrm{VO}_{3} \cdot 7 \mathrm{H}_{2} \mathrm{O}$ (as a precursor of vanadate anions). The final hydrotalcites were formed at $\mathrm{pH}$ range of 9.5-10.5. $\mathrm{Mg} / \mathrm{Al}$ ratio was adapted in order to reach 2:1, 3:1 and 4:1 hydrotalcite structure. The reference sample was hydrotalcite prepared with carbonate anions. X-ray diffraction analysis of the resulting materials indicated the presence of characteristic hydrotalcite spacing $\mathrm{d}_{(003)}$ in range of 7.6-8.0 $\AA$. Changes in the diffractogram after the incorporation of oxometalates point at the disparity in the interlayer distance of the LDHs. Increase in interlayer distance resulted in larger $\mathrm{d}_{(003)}$ space. Hence, distinguishing of the route of inclusion of the anion (adsorption or intercalation) was possible. Considering 2:1 hydrotalcites, $d_{(003)}$ spacing remained unchanged for the materials with vanadate anions, in comparison to the reference sample. It suggests that anionic vanadate species are adsorbed on the interlayer surface. However, for 3:1 and 4:1 hydrotalcites, a considerable increase in (003) reflection was observed. The occurrence is explained by intercalation of vanadate ions that are much greater than the reference carbonates and forcing the hydroxyl layers apart, with the simultaneous increase of interlayer space.

\section{Molybdate anions}

Except the vanadate anions, there are also several studies concerned on incorporation of molybdate anions into the interlayer space of $\mathrm{LDHs}^{44}$. ${ }^{45}$. Molybdenum, as one of the components of the commercial SCR catalyst provides high stability of the system and some amount of active sites. Therefore, it is predicted that molybdate anions may have a promoting influence as the components of LDHs applied for $\mathrm{NO}_{x}$ removal via selective catalytic reduction. Ciocan et al. ${ }^{44}$ reported an facile method to prepare Mo-containing LDHs catalysts by ion exchange. In order to intensify the process and to obtain ordered structure of the materials, the exchange was performed during aging under hydrothermal conditions. For comparative purposes, the material was also prepared via ion exchange without applying hydrothermal treatment. SEM analysis performed on the prepared samples proved that both materials are consisted of pellets or agglomerates. However, the application of hydrothermal conditions during the synthesis resulted in better crystallinity of the sample.

Molybdate anionic species can be introduced into interlamellar space in the various forms. In order to study the nature of interlayer anions, the Mo-containing LDHs were examined by Raman spectroscopy. The study indicated the presence of the characteristic peaks assigned to the lattice vibrations of the $\mathrm{Al}-\mathrm{O}-\mathrm{Al}$ and $\mathrm{Al}-\mathrm{O}-\mathrm{Mg}$ (brucite octahedral layers) at $557 \mathrm{~cm}^{-1}$, for parent material and nitrate vibrations at 1050 and 709 $\mathrm{cm}^{-1}$. However, after incorporation of molybdate anions these peaks disappeared completely. Therefore, it can be concluded that under the hydrothermal conditions, nearly all of the nitrate anions from the starting material were successfully exchanged. The most important frequencies that belong to the three types of anions: $\mathrm{MoO}_{4}{ }^{2-}$, $\mathrm{Mo}_{7} \mathrm{O}_{24}{ }^{6-}$ and $\mathrm{Mo}_{2} \mathrm{O}_{7}{ }^{2-}$ are in the domain $890-950 \mathrm{~cm}^{-1}$. The results are in full agreement with the similar study carried out by Dobrea et al. ${ }^{45}$ who examined the dependence of the nature of molybdate anions on the loading of these species. Additionally, both authors proved that heptamolybdate anions were the most dominant species. The Raman spectra obtained for materials prepared with various Mo loading indicated that the more Mo was introduced into the interlayer space, the more complex is the spectra and octahedrally coordinated polymolybdate species $\left(\mathrm{Mo}_{2} \mathrm{O}_{7}{ }^{2-}\right.$ and $\left.\mathrm{Mo}_{7} \mathrm{O}_{24}{ }^{6-}\right)$ are formed.

\section{MODIFIED LDHS AS CATALYSTS OF SELECTIVE CATALYTIC REDUCTION OF NO $\mathrm{X}_{\mathrm{x}}$ WITH AMMONIA}

Many researchers proved that layered double hydroxides, including hydrotalcite-originated mixed metal oxides are promising materials that can be used in selective catalytic reduction with ammonia ${ }^{12,14,15}$.

Carja et al. ${ }^{6}$ carried out $\mathrm{NH}_{3}$-SCR catalytic tests over mixed oxides derived from pillared oxovanadates. In order to increase the catalytic performance of the materials, the selected samples were ion-exchanged with copper species. LDHs were prepared using co-precipitation, with a careful control of $\mathrm{pH}$. In all cases, the aqueous solutions of $\mathrm{Mg}$ and $\mathrm{Al}$ or $\mathrm{Mg}, \mathrm{Al}$ and $\mathrm{Cu}$ cations was dropwise added to the $\mathrm{NaVO}_{3} / \mathrm{NaOH}$ mixture at the desired $\mathrm{pH}$ (8.5-9.5). The gelatinous suspension were heated at certain temperature for several hours. The certain $\mathrm{pH}$ applied during the synthesis resulted in the predomination of $\mathrm{V}_{2} \mathrm{O}_{7}^{4-}$ and $\mathrm{HV}_{2} \mathrm{O}_{7}{ }^{3-}$ in the obtained aqueous mixture. The basal spacing between the layers of LDHs was determined by X-ray diffraction. It was $9.18 \AA$ and $8.97 \AA$ for the samples unmodified and modified with copper, respectively and the thickness of brucite layer was $4.8 \AA$. Therefore, the interlayer spacing that is occupied by vanadate ions equals $4.38 \AA$ and $4.27 \AA$ for samples without and with $\mathrm{Cu}$, respectively. It indicates, that oxovanadate anions are incorporated into interlayer space in "lying down" position and V-V axis in two $\left[\mathrm{VO}_{4}\right]$ tetrahedra are parallel to the layers. Analysis of the chemical composition proved that enrichment in vanadium occurs for the samples that contain copper. Therefore, the presence of transition metal increase the efficiency of pillaring with oxovanadates. Additionally, the presence of oxovanadates as interlayer anions was proved by Fourier transform infrared spectroscopy (FT-IR) analysis. Catalytic tests carried out over the oxovanadatepillared LDHs and the same materials modified with $\mathrm{Cu}$ demonstrated approximately equivalent $\mathrm{NO}$ conversion for both materials. However, for the samples promoted with $\mathrm{Cu}$, the maximum conversion of $\mathrm{NO}$ was reached at lower temperature $\left(350^{\circ} \mathrm{C}\right)$. Additionally, that case, only negligible formation of $\mathrm{N}_{2} \mathrm{O}$ (about $10-20 \mathrm{ppm}$ ) was observed. On the other hand, above $400^{\circ} \mathrm{C}$ coppercontaining catalyst exhibited a tendency to catalyse undesired reaction of ammonia oxidation. High catalytic activity of vanadium containing catalysts was explained by the relation of SCR activity with the surface acidity caused by the $\mathrm{V}^{5+}-\mathrm{OH}$ sites. In view of the above, the further research over $\mathrm{V}$ - and $\mathrm{Cu}$-containing LDHs needs to focus on their coexistence in appropriate amount, so that both catalytic activity and selectivity are enhanced.

Montanari et al. ${ }^{46}$ studied the influence of the content of the transition metal in $\mathrm{Cu}-\mathrm{Mg}-\mathrm{Al}-\mathrm{O}_{\mathrm{x}}$ synthesised via co-precipitation, followed by calcination of hydrotalcitelike precursors at $650^{\circ} \mathrm{C}$. The loading of copper oxide was calculated to reach between $4.0-12.5 \mathrm{wt} \%$. The reference 
sample was represented by $\mathrm{Mg}-\mathrm{Al}-\mathrm{O}_{\mathrm{x}}$ impregnated with $10 \mathrm{wt} \%$ of copper oxide. Comparing the nature of copper species in both cases, impregnation method resulted in the formation of crystalline $\mathrm{CuO}$, while for the materials prepared by co-precipitation $\mathrm{CuO}$ segregation did not occur. Catalytic tests carried out over the materials indicated that in case of $12.5 \mathrm{wt} \%$ loading of copper oxide, $\mathrm{NO}$ was completely reduced at $350^{\circ} \mathrm{C}$ and decrease of the copper oxide results in the lower catalytic activity. However, it was observed that the catalytic performance was significantly higher in the whole temperature range $\left(150-500^{\circ} \mathrm{C}\right)$ for the catalyst obtained by impregnation. The results were in full agreement with $\mathrm{H}_{2}$-TPR analysis of the prepared materials. The catalysts impregnated with $\mathrm{Cu}^{2+}$ showed lower reduction temperature of about $200^{\circ} \mathrm{C}$, while hydrotalcite-derived mixed metal oxides were reduced in the temperature between 240 and $300^{\circ} \mathrm{C}$. Therefore, significantly higher catalytic performance of CuO-containing materials is the result of the lower reduction temperature.

Carja et al. (2009) presented alternative attempt to use hydrotalcite-like compounds as $\mathrm{NH}_{3}$-SCR catalysts. Calcined iron-substituted LDHs Mg-Al-Fe-O were modified with aqueous solutions of iron and cerium sulphates, in order to deposit $\mathrm{Fe}_{2} \mathrm{O}_{3}$ and $\mathrm{CeO}_{2}$ on the hydrotalcite-like support. Subsequently, the samples were calcined at $550^{\circ} \mathrm{C}$. Catalytic tests indicated that the catalysts containing $\mathrm{CeO}_{2}$ showed considerably higher activity below $250^{\circ} \mathrm{C}$, while above this temperature, samples doped with $\mathrm{Fe}_{2} \mathrm{O}_{3}$ exhibited higher conversion of NO. The effect might be caused by the low thermal resistance of $\mathrm{CeO}_{2}$ as a promoter of $\mathrm{NH}_{3}$-SCR in the high temperature range.

$\mathrm{Xu}$ et al. prepared $\mathrm{CoMnAl}-\mathrm{CO}_{3}$ and $\mathrm{CoAl}-\mathrm{MnO}_{2}$ LDHs via ion-exchange and hexamethylenetetramine (HMT) hydrolysis. Mixed metal oxides $\mathrm{Co}-\mathrm{Mn}-\mathrm{Al}$ and $\mathrm{MnO}_{2}$-Co-were formed upon calcination at $500^{\circ} \mathrm{C}$. The obtained materials were tested as catalysts of $\mathrm{NH}_{3}$-SCR. It was found that the samples obtained by ion-exchange show significantly higher catalytic activity. $\mathrm{MnO}_{2}$ - $\mathrm{Co}-\mathrm{Al}$ exhibited $90 \%$ of NO conversion and $95 \%$ selectivity to $\mathrm{N}_{2}$ in the temperature range of $90-270^{\circ} \mathrm{C}$. The same results were obtained for $\mathrm{Co}-\mathrm{Mn}-\mathrm{Al}$ that were obtained at about $150-240^{\circ} \mathrm{C}$. Brauner-Emmet-Teller (BET) surface area analysis of the materials indicated higher specific surface area of $\mathrm{MnO}_{2}-\mathrm{Co}-\mathrm{Al}\left(156.8 \mathrm{~m}^{2} / \mathrm{g}\right)$ in comparison to $\mathrm{Co}-\mathrm{Mn}-\mathrm{Al}\left(85.3 \mathrm{~m}^{2} / \mathrm{g}\right)$. Additionally, $\mathrm{MnO}_{2}-\mathrm{Co}-\mathrm{Al}$ exhibited more narrow pore size distribution $(3-7 \mathrm{~nm})$ than the other material $(3-20 \mathrm{~nm})$. Hence, the adsorption of the reagents on the internal surface of $\mathrm{MnO}_{2}$-Co-Al was facilitated. $\mathrm{H}_{2}$-TPR study showed that all of the reduction peaks detected for $\mathrm{MnO}_{2}-\mathrm{Co}-\mathrm{Al}$ shifted to lower temperature regions of about $250-600^{\circ} \mathrm{C}$, in contrast to $\mathrm{Co}-\mathrm{Mn}-\mathrm{Al}$ that was reduced at about $370-650^{\circ} \mathrm{C}$. NOTPD analysis carried out over the catalysts revealed one large desorption peak for $\mathrm{MnO}_{2}$ - $\mathrm{Co}-\mathrm{Al}$ at $158^{\circ} \mathrm{C}$ indicating the presence of monodentate nitrate species. In contrast, several peaks below $200^{\circ} \mathrm{C}$, at $255^{\circ} \mathrm{C}$ and at $305^{\circ} \mathrm{C}$ were detected for Co-Mn-Al. According to the authors, the signals are assigned to the decomposition of monodentate, bridging and bidentate nitrate species, respectively. It was reported that monodentate nitrates have a positive influence on the catalytic activity in
$\mathrm{NH}_{3}$-SCR. Therefore it was concluded that one of the reasons of the better catalytic performance of $\mathrm{MnO}_{2}$ $\mathrm{Mn}-\mathrm{Al}$ was the facilitated adsorption of these species on the surface of the catalyst.

\section{CONCLUSIONS}

Layered double hydroxides are the class of materials with a strong potential as catalysts for the reduction of nitrogen oxides from the industrial sources. Wide variety of the chemical compositions of LDHs was tested to develop active, selective and stable catalyst of $\mathrm{NH}_{3}$-SCR. Excellent structural properties of the materials make them an attractive precursors for catalysts and catalysts supports. The number of studies showed that especially inclusion of transition metals in various forms into the LDHs and their transformation into mixed metal oxides results in high catalytic activity. However, one of the main problems that still needs to be resolved is broad operating temperature window of these materials. Moreover, LDHs should be also tested using gas mixtures that mimic real composition of exhaust gases. Therefore, further studies under real conditions and tailoring LDHs-based catalysts active in the wide temperature range still remains a challenge.

\section{ACKNOWLEDGEMENTS}

The research was financed by AGH Grant 16.16.210.476.

\section{LITERATURE CITED}

1. The European Parliament and the Council of the European Union. (2010). Directive 2010/75/EU of the European Parilament and of the Council of 24 November 2010 on industrial emissions (integrated pollution prevention and control). Official Journal of the European Union 17.12.2010.

2. Samojeden, B. \& Grzybek, T. (2016). The influence of the promotion of $\mathrm{N}$-modified activated carbon with iron on NO removal by $\mathrm{NH}_{3}$-SCR (Selective catalytic reduction). Energy. 116, 1484-1491. DOI: 10.1016/j.energy.2016.04.059.

3. Gao, F., Tang, X., Yi, H., Zhao, S., Li, C., Li, J., Shi Y. \& Meng, X. (2017). A Review on Selective Catalytic Reduction of $\mathrm{NO}_{x}$ by $\mathrm{NH}_{3}$ over Mn-Based Catalysts at Low Temperatures: Catalysts, Mechanisms, Kinetics and DFT Calculations. Catalysts, 7(7), 199. DOI: 10.3390/catal7070199.

4. Samojeden, B. \& Grzybek, T. (2017). The influence of nitrogen groups introduced onto activated carbons by high- or lowtemperature $\mathrm{NH}_{3}$ treatment on $\mathrm{SO}_{2}$ sorption capacity. Adsorpt. Sci. Technol. 35(5-6), 572-581. DOI: 10.1177/0263617417702153.

5. Motak, M., Kuterasiński, Ł., Da Costa, P. \& Samojeden, B. (2015). Catalytic activity of layered aluminosilicates for VOC oxidation in the presence of $\mathrm{NO}_{\mathrm{x}}$. Comptes Rendus Chim. 18(10), 1106-1113. DOI: 10.1016/j.crci.2015.05.005.

6. Carja, G. \& Delahay, G. (2004). Mesoporous mixed oxides derived from pillared oxovanadates layered double hydroxides as new catalysts for the selective catalytic reduction of NO by $\mathrm{NH}_{3}$. Appl. Catal. B. Environ. 47(1), 59-66. DOI: 10.1016/j. apcatb.2003.07.004.

7. Cheng, M., Jiang, B., Yao, S., Han, J., Zhao, S., Tang, X., Zhang, J. \& Wang, T. (2018). Mechanism of $\mathrm{NH}_{3}$ Selective Catalytic Reduction Reaction for $\mathrm{NO}_{\mathrm{x}}$ Removal from Deiesel Engine Exhaust and Hydrothermal Stability of Cu-Mn/Zeolite Catalyst. J. Phys. Chem. 122(1), 455-464. DOI: 10.1021/acs. jpcc.7b09339.

8. Koebel, M., Elsener, M. \& Kleemann, M. (2000). UreaSCR: a promising technique to reduce $\mathrm{NO}_{\mathrm{x}}$ emissions from 
automotive diesel engines. Catal. Today. 59(3-4), 335-345. DOI: 10.1016/S0920-5861(00)00299-6.

9. Grzybek, T. (2007). Layered clays as SCR deNO catalysts. Catal. Today. 119(1-4), 125-132. DOI: 10.1016/j. cattod.2006.08.006.

10. Peng, Y., Li, J., Si, W., Luo, J., Wang, Y., Fu, J., Li, X., Crittenden, J. \& Hao, J. (2015). Deactivation and regeneration of a commercial SCR catalyst: Comparison with alkali metals and arsenic. Appl. Catal. B Environ. 168-169, 195-202. DOI: 10.1016/j.apcatb.2014.12.005.

11. Chang, H., Shi, C., Li, M., Zhang, T., Wang, C., Jiang, L., Wang, X. (2018). The effect of cations $\left(\mathrm{NH}_{4}{ }^{+}, \mathrm{Na}^{+}, \mathrm{K}^{+}\right.$, and $\mathrm{Ca}^{2+}$ ) on chemical deactivation of commercial SCR catalyst by bromides. Chinese J. Catal. 39(4), 710-717. DOI: 10.1016/ S1872-2067(18)63011-6.

12. Basąg, S., Kocoł, K., Piwowarska, Z., Rutkowska,M., Baran, R. \& Chmielarz, L. (2017). Activating effect of cerium in hydrotalcite derived $\mathrm{Cu}-\mathrm{Mg}-\mathrm{Al}$ catalysts for selective ammonia oxidation and the selective reduction of NO with ammonia. React. Kinet. Mech. Catal. 121(1), 225-240. DOI: 10.1007/s11144-017-1141-y.

13. Wu, X., Feng, Y., Du, Y., Liu, X., Zou, C. \& Li, Z. (2019). Enhancing $\mathrm{DeNO}_{\mathrm{x}}$ performance of CoMnAl mixed metal oxides in low-temperature NH3-SCR by optimizing layered double hydroxides (LDHs) precursor template. Appl. Surf. Sci. 467-468, 802-810. DOI: 10.1016/j.apsusc.2018.10.191.

14. Jabłońska, M., Nothdurft, K., Nocuń, M., Girman, V. \& Palkovits, R. (2017). Redox-performance correlations in $\mathrm{Ag}-\mathrm{Cu}-\mathrm{Mg}-\mathrm{Al}, \mathrm{Ce}-\mathrm{Cu}-\mathrm{Mg}-\mathrm{Al}$, and $\mathrm{Ga}-\mathrm{Cu}-\mathrm{Mg}-\mathrm{Al}$ hydrotalcite derived mixed metal oxides. Appl. Catal. B Environ. 207, 385-396. DOI: 10.1016/j.apcatb.2017.01.079.

15. Chmielarz, L., Jabłońska, M., Strumiński, A., Piwowarska, Z., Węgrzyn, A., Witkowski, S. \& Michalik, M. (2013). Selective catalytic oxidation of ammonia to nitrogen over $\mathrm{Mg}-\mathrm{Al}, \mathrm{Cu}-\mathrm{Mg}-\mathrm{Al}$ and $\mathrm{Fe}-\mathrm{Mg}-\mathrm{Al}$ mixed metal oxides doped with noble metals. Appl. Catal. B Environ. 130-131, 152-162. DOI: $10.1016 /$ j.apcatb.2012.11.004.

16. Xu, Z.P., Zhang, J., Adebajo, M.O., Zhang, H. \& Zhou, C. (2011). Catalytic applications of layered double hydroxides and derivatives. Appl. Clay Sci. 53(2), 139-150. DOI: 10.1039/ C4CS00160E.

17. Forano, C., Costantino, U., Prévot, V. \& Gueho, C.T. (2013). Layered Double Hydroxides (LDH). In F. Bergaya and G. Lagaly (Eds.), Handbook of clay science 745-782. Elsevier.

18. Rives, V. \& Ulibarri, M.A. (1999). Layered double hydroxides (LDH) intercalated with metal coordination compounds and oxometalates. Coord. Chem. Rev. 181(1), 61-120. DOI: 10.1016/S0010-8545(98)00216-1.

19. Meyn, M., Beneke, K. \& Lagaly, G. (1990). Anionexchange reactions of layered double hydroxides. Inorg. Chem. 29(26), 5201-5207. DOI: 10.1021/ic00351a013.

20. Jabłońska, M., Chmielarz, L. \& Węgrzyn, A. Chemii, W. (2013). Selektywne katalityczne utlenianie (SCO) amoniaku do azotu i pary wodnej wobec mieszanych tlenków pochodzenia hydrotalkitowego - praca przeglądowa. Chemik. 8, 701-710. YADDA identificator: bwmeta1.element.baztech-6167861c0171-499d-b857-8e5d837c4b2f.

21. Prasanna, S.V., Kamath, P.V. \& Shivakumara, C. (2007). Synthesis and characterization of layered double hydroxides (LDHs) with intercalated chromate ions. Mater. Res. Bull. 42(6), 1028-1039. DOI: 10.1016/j.materresbull.2006.09.021.

22. Chmielarz, L., Ku, P., Majda, D. \& Dziembaj, R. (2002). Catalytic activity of $\mathrm{Co}-\mathrm{Mg}-\mathrm{Al}, \mathrm{Cu}-\mathrm{Mg}-\mathrm{Al}$ and $\mathrm{Cu}-\mathrm{Co}-\mathrm{Mg}-\mathrm{Al}$ mixed oxides derived from hydrotalcites in SCR of NO with ammonia. Appl. Catal. B Environ. 35, 195-210. DOI: 10.1016/ S0926-3373(01)00254-5.

23. Miyata, S. (1983). Anion-Exchange Properties of Hydrotalcite-Like Compounds. Clays Clay Miner. 31(4), 305-311. DOI: 10.1346/CCMN.1983.0310409.
24. Wang, Q., Wu, Z., Tay, H.H., Chen, L., Liu, Y., Chang, J., Zhong, Z., Luo, J. \& Borgna, A. (2011). High temperature adsorption of $\mathrm{CO}_{2}$ on $\mathrm{Mg}$-Al hydrotalcite: Effect of the charge compensating anions and the synthesis pH. Catal. Today. 164(1), 198-203. DOI: 10.1016/j.cattod.2010.10.042.

25. Li, K., Kumada, N., Yonesaki, Y., Takei, T., Kinomura, N., Wang, H. \& Wang, C. (2010). The pH effects on the formation of $\mathrm{Ni} / \mathrm{Al}$ nitrate form layered double hydroxides (LDHs) by chemical precipitation and hydrothermal method. Mater. Chem. Phys. 121(1-2), 223-229. DOI: 10.1016/j.matchemphys.2010.01.026.

26. Ghosal, P.S., Gupta, A.K. \& Ayoob, S. (2015). Effect of formation $\mathrm{pH}$, molar ratio and calcination temperature on the synthesis of an anionic clay based adsorbent targeting defluoridation. Appl. Clay Sci. 116-117, 120-128. DOI: 10.1016/j. clay.2015.08.026.

27. Comelli, N.,A., Ruiz, M.,L., Aparicio, M.S.L., Merino, N.A., Cecilia, J.A., Rodrínguez-Castellón, E., Lick, I.D. \& Ponzi, M.I. (2018). Influence of the synthetic conditions on the composition, morphology of $\mathrm{CuMgAl}$ hydrotalcites and their use as catalytic precursor in diesel soot combustion reactions. Appl. Clay Sci. 157, 148-157. DOI: 10.1016/j.clay.2018.02.039.

28. Ramos-Ramírez, E., Ortega, N.L.G., Soto, C.A.C., Gutiérrez, M.T.O. (2009). Adsorption isotherm studies of chromium (VI) from aqueous solutions using sol-gel hydrotalcite-like compounds. J. Hazard. 172(2-3), 1527-1531. DOI: 10.1016/j. jhazmat.2009.08.023.

29. Prinetto, F., Ghiotti, G., Graffin, P. \& Tichit, D. (2000). Synthesis and characterization of sol-gel $\mathrm{Mg} / \mathrm{Al}$ and $\mathrm{Ni} / \mathrm{Al}$ layered double hydroxides and comparison with co-precipitated samples. Micropor. Mesopor. Mater. 39(1-2), 229-247. DOI: 10.1016/S1387-1811(00)00197-9.

30. Jabłońska, M., Arán, M.A., Beale, A.M., Delahay, G., Petitto, C., Nocuń, M. \& Palkovits, R. (2019). Understanding the origins of $\mathrm{N}_{2} \mathrm{O}$ decomposition activity in $\mathrm{Mn}(\mathrm{Fe}) \mathrm{CoAlO}_{\mathrm{x}}$ hydrotalcite derived mixed metal oxides. Appl. Catal. B Environ. 243, 66-75. DOI: 10.1016/j.apcatb.2018.10.010.

31. Wang, Z., Li, Q., Wang, L. \& Shangguan, W. (2012). Simultaneous catalytic removal of $\mathrm{NO}_{\mathrm{x}}$ and soot particulates over $\mathrm{CuMgAl}$ hydrotalcites derived mixed metal oxides. Appl. Clay Sci. 55, 125-130. DOI: 10.1016/j.clay.2011.11.003.

32. Mascolo, G. \& Mascolo, M.C. (2015). On the synthesis of layered double hydroxides (LDHs) by reconstruction method based on the "memory effect". Micropor. Mesopor. Mater. 214, 34-36. DOI: 10.1016/j.micromeso.2015.03.024.

33. Rivera, J.A., Fetter, G. \& Bosch, P. (2006). Microwave power effect on hydrotalcite synthesis. Micropor. Mesopor. Mater. 89(1-3), 306-314. DOI: 10.1016/j.micromeso.2005.10.041.

34. Zhi, P.X. \& Guo, Q.L. (2005). Hydrothermal synthesis of layered double hydroxides ( $\mathrm{LDHs}$ ) from mixed $\mathrm{MgO}$ and $\mathrm{Al}_{2} \mathrm{O}_{3}$ : LDH formation mechanism. Chem. Mater. 17(5), 1055-1062. DOI: $10.1021 / \mathrm{cm} 048085 \mathrm{~g}$.

35. Genty, E., Brunet, J., Poupin, C., Casale, S., Capelle, S., Massiani, P., Siffert, S. \& Cousin, R. (2015). Co-Al Mixed Oxides Prepared via LDH Route Using Microwaves or Ultrasound: Application for Catalytic Toluene Total Oxidation. Catalysts. 5(2), 851-867. DOI: 10.3390/catal5020851.

36. Vaccari, A. (1998). Preparation and catalytic properties of cationic and anionic clays. Catal. Today. 41(1-3), 53-71. DOI: 10.1016/S0920-5861(98)00038-8.

37. Palmer, S.J., Soisonard, A. \& Frost, R.L. (2009). Determination of the mechanism(s) for the inclusion of arsenate, vanadate, or molybdate anions into hydrotalcites with variable cationic ratio. J. Colloid Interface Sci. 329(2), 404-409. DOI: 10.1016/j.jcis.2008.09.065.

38. Palomeque, J., Figueras, F. \& Gelbard, G. (2006). Epoxidation with hydrotalcite-intercalated organotungstic complexes. Appl. Catal. A Gen. 300(2), 100-108. DOI: 10.1016/j. apcata.2005.10.037. 
39. Liu, K., Xu, Y., Yao, Z., Miras, H.N. \& Song, Y.F. (2016). Polyoxometalate-Intercalated Layered Double Hydroxides as Efficient and Recyclable Bifunctional Catalysts for Cascade Reactions. ChemCatChem. 8(5), 929-937. DOI: 10.1002/cctc.201501365.

40. Chen, F., Wu, X., Bu, R. \& Yang, F. (2017). Co - Fe hydrotalcites for efficient removal of dye pollutants via synergistic adsorption and degradation. RSC Advances. 7, 41945-41954. DOI: $10.1039 /$ C7RA07417D.

41. Stępniowski, W.J., Norek, M., Michalska-Domańska, M., Bombalska, A., Nowak-Stępniowska, A., Kwaśny, M. \& Bojar, Z. (2012). Fabrication of anodic aluminum oxide with incorporated chromate ions. Appl. Surf. Sci. 259, 324-330. DOI: 10.1016/j.apsusc.2012.07.043.

42. Zhou, W., Tian, P., Sun, F., He, M. \& Chen, Q. (2016). Highly efficient transformation of alcohol to carbonyl compounds under a hybrid bifunctional catalyst originated from metalloporphyrins and hydrotalcite. J. Catal. 335, 105-116. DOI: 10.1016/j.jcat.2015.11.017.

43. Conterosito, E., Palin, L., Antonioli, D. \& Viterbo, D. (2015). Structural Characterisation of Complex Layered Double Hydroxides and TGA-GC-MS Study on Thermal Response and Carbonate Contamination in Nitrate- and Organic-Exchanged Hydrotalcites. Chem.; Eur. J. 21, 14975-14986. DOI: 10.1002/ chem.201500450.

44. Ciocan, C.E., Dumitriu, E., Cacciaguerra, T., Fajula, F. \& Hulea, V. (2012). New approach for synthesis of Mo-containing LDH based catalysts. Catal. Today. 198(1), 239-245. DOI: 10.1016/j.cattod.2012.04.071

45. Dobrea, I.D., Ciocan, C.E., Dumitriu, E., Popa, M.I., Petit, E. \& Hulea, V. (2015). Raman spectroscopy - Useful tool for studying the catalysts derived from Mo and V-oxyanionintercalated layered double hydroxides. Appl. Clay Sci. 104, 205-210. DOI: 10.1016/j.clay.2014.11.034.

46. Montanari, B., Vaccari, A., Gazzano, M., Kässner, P., Papp, H., Pasel, J., Dziembaj, R., Makowski, W. \& Lojewski, T. (1997). Characterization and activity of novel coppercontaining catalysts for selective catalytic reduction of $\mathrm{NO}$ with $\mathrm{NH}_{3}$. Appl. Catal. B Environ. 13, 205-217. DOI: 10.1016/ S0926-3373(96)00106-3.

47. Twu, J. \& Dutta, K. (1990). Decavanadate Ion-Pillared Hydrotalcite: Spectroscopic Studies of the Thermal Decomposition Process. J. Catal. 510, 503-510. DOI: 10.1016/00219517(90)90196-Q.

48. Jabłońska, M. \& Palkovits, R. (2015). Nitrogen oxide removal over hydrotalcite-derived mixed metal oxides. Catal. Sci. Technol. 6(1), 49-72. DOI: 10.1039/c5cy00646e.

49. Carja, G., Dranca, S., Husanu, E. \& Volf, I. (2009). Iron Containing Anionic Clays Supported With Iron Andcerium Oxides As Catalyst Precursors for $\mathrm{NO}_{\mathrm{x}}$ Reduction. Environ. Eng. Manag. J. 8(3), 553-557. DOI: 10.30638/eemj.2009.076.

50. Wu, X., Feng, Y., Du, Y., Liu, X., Zou, C. \& Li, Z. (2019). Enhancing $\mathrm{DeNO}_{\mathrm{x}}$ performance of CoMnAl mixed metal oxides in low-temperature $\mathrm{NH}_{3}$-SCR by optimizing layered double hydroxides (LDHs) precursor template. Appl. Surf. Sci. 467-468, 802-810. DOI: 10.1016/j.apsusc.2018.10.191 . 